\title{
A marca de Barbados
}

\author{
Marıa Amélia Schmidt Dickie \\ Universıdade Federal de Santa Catarma Florianopolıs Brasil \\ marıadıckı@yahoocom
}

$\mathrm{m}$ 1974, eu procurava uma alternativa ao que a formatura em
Direito me apresentava No Museu de Antropologia da UFSC, eu ouvira falar, havia um estagıo que podıa bem servır como untrodução ao campo da discıplına La fuı eu tentar um processo de seleção Só sabıa que era bom, conversa de alunos num semuárı em que o assunto veı à tona Naquele janeiro, conheci o Sílvıo Não lembro os detalhes de minha chegada ao Museu exceto que, na sala dele, depors de uma pequena entrevista ouvı sobre o pıograma a ser desenvolvido e o projeto do Museu de formar estudantes na área de Antropologia Ouvı tambem sobre os trabalhos de pesquisa que o Museu ja fazıa, os nomes dos pesquisadores que, na hora, não sıgnifıcaram muito para mım, e suas áreas de interesse Lembro que a prımeira impressão for a de ter encontrado um homem que falava muito e que tinha muita certeza sobie o que falava For nesta conversa do Sílvı que conhecı tambem o maıs autêntıco sotaque ılhéu ılustrado Não posso deıxar de sorrir lembrando meu entusiasmo com o aceite de minha candıdatura e o sorrıso aberto dele, com brilho inquisıdor nos olhos, enquanto falava 
Aprendı depoıs, ao longo dos anos de convivêncıa, que o brılho nos olhos era uma constante quando falava de Antropologia ou de suas convıcções O sorrıso aberto reservava para a alegrıa e, as vezes, para a uronia Neste caso, era o sorrıso meıo de lado, com a gestualıdade tensa dos braços e com o olhar de brilho cortante o brilho inquirıdor fol, junto com o sorriso, o que mais constantemente vi no Silvio nos dois anos de estagio no Museu Ao ensinar, eram estes que afloravam, nunca o da rronıa $\mathrm{O}$ ınquisıdor nos desafıava ao racıocínıo e a criatıvidade, o sorrıso aberto nos dizıa que valıa a pena arriscar por estes campos E o dialogo em momentos tensos, sempre uma possıbilidade

Na minha memórıa de estagıarıa, o espaço do Museu é o utero gestador No andar de cuma, Jane ${ }^{1}$ e eu compartılhávamos a sala dos pesquisadores ${ }^{2}$, e éramos contaminadas pelas atividades ao nosso redor Na biblioteca, com sua mesa comprida, semanalmente prestavamos conta dos textos lidos e ensalavamos argumentar antropologia nos semunárıos temátıcos orıentados pelos pesquisadores A sala de aula, com um enorme quadro onde pudemos desenhar muitos esquemas de parentesco para conseguir entender as 'trocas de mulheres' ou os "grupos de sıblıngs" Ao lado, no topo da escada, a sala do Sílvı era o espaço onde so se entrava a convite ou com um polıdo pedido de licença

Sala pequena, mesa grande, o armario duas poltronas para os visitantes, vaso de plantas Na estante sob a janela artefatos indigenas, lıvros revistas e papéis escritos Nas paredes, gravuras e desenhos de Fossarı e de Alair Uma sala improvisada, como a maıoria das salas na UFSC naqueles tempos, mas uma sala expressiva de seu ocupante Ordenada, fazendo o melhor com o que tinha à mão, ao mesmo tempo contendo mais do que seria de se esperar pelos limites fisicos de seu espaço Sala onde eram recebıdos os visitantes, as autorıdades, os colegas, os pesquisadores e os Xokleng que o visıtavam Sala testemunha das muıtas artıculações que consolıdaram o Museu e o lugar da Antropologia na UFSC

Naquele ano de 1974, de muitos medos, o ambiente do Museu era o de confrança Confıança que se traduzıa na abertura das discussões e nas responsabilidades politıcas que Silvio e os demais pesquisadores atrıbuíam a Antropologıa e com a qual nos impregnaram A Antropo- 
logı que aprendı naquele ambiente foı uma Antropologıa atenta aos problemas socıaıs, atenta as minorias, uma Antropologia que não se furtava ao debate polıtıco, antes, fazıa dele um projeto e um proposı to Era um ano após a reunıão de Barbados, e desta reunıão falava-se muito, lia-se muito o que alı havia sido produzıdo, e crcscia-se muito a partır de suas conclusões As lıções de Sılvıo eram sempre enfatıcas, polêmıcas, quase retumbantes e sempre estımulantes Como aluna, mutas vezes me indignava com sua veemêncıa Outras, era desafiada ao extremo e impelıda a falar ıdeıas ainda não amadurecıdas com uma ênfase que elas não merecıam Jamaıs fuı cortada Sempre havıa da parte dele a provocação criatıva que me deıxava remoendo minha ımaturıdade e me impelıa aos lıvros durante toda a proxıma semana, até o semmáno seguinte

Esta sistematica era seguida por todos os pesquisadores que dırıgıam os semunárıos Mas, se com eles os estagıarıos havıam conseguido estabelecer uma convivência unformal, de companheiros de trabalho, com Sílvio ficava clara a hierarquıa Só no fim do ano, quando ele e Alair nos recebiam em sua casa de praia, e ele assava excelentes churrascos para festejarmos as atıvidades do ano passado, o professor Sılvıo virava Silvıo, contava mutas historias, ıla conosco das piadas sobre o cotıdiano dos trabalhos de campo, sobre nossa vivência no Museu, e, sım, infaluvelmente, no entusıasmo do que hava sıdo realızado falávamos dos projetos para os futuros, proxımos e distantes e a importância de chegarmos la

Como diretor do Museu, um dos primordıaıs projetos de Sílvıo foı a formação de antropólogos A aceıtação de estagıarıos ${ }^{3}$ era um passo, dizıa ele, para seguumos mestrado e doutorado Por isto, ir a campo com os pesquisadores, seja para escavações arqueológıcas seja para a etnografia de pescadores seja para uma visita a T I dos Xokleng era uma exıgêncıa do estágıo Junto dısto, Sílvıo fol um incansável estı mulador de estágıos em outras instıtuıções, aos cursos de mestrado e doutorado dos pesquisadores do Museu, e promoveu a visita de diversos antropólogos brasileiros e estrangciros para cursos e conferencias às quais assistíamos com o entusiasmo de inıciantes motıvados Sílvı nos tremou $E$ parte deste tremamento sintetiza todo o resto fomos 
partıcıpes de todo o processo de organızação e realızação da Reunıão da Assocıação Brasıleura de Antropologıa, em Dezembro daquele ano, na UFSC Ainda que Sílvı sempre remeta a Oswaldo Cabral a paternıdade da Antropologıa catarınense, e de Sılvıo o merıto de tê la unscrito na esfera da excelência da UFSC

Ao longo destes anos, desde 1974 em que o professor Sílvio se tornou definıtıvamente Sílvio, colega e mestre permaneceu comıgo a marca daquele ano, que eu chamo de marca de Barbados porque do compromusso etico e politico daquele momento derivou para todos os alunos dele a Antropologia que se pensa estrategica e se desenvolve por múltıplos camunhos De Sílvo, sempre, o exemplo e a coerêncıa da grande generosıdade com que reparte seus saberes e sua vida profıssional, ao rastro indelével que sua trajetorıa forjou no grupo que tem o privilegıo de conviver com ele na UFSC Durante todo o percurso, o mesmo Sílvio, jamaıs cansado, jamaıs desıstundo, o Sílvıo de luta e o Sílvıo amıgo

Flonanopolıs, 20 de outubro 2008

\section{Notas}

1 Jane Beltrão for estagıarıa junto comıgo

2 Marıa Jose Reıs Neusa Bloemer Alromo Eble Luıs Carlos Halfpap Anamarıa Beck que se tornou munha onentadora tinha sua sala no andar terreo junto ao laboratorio de arqueologia

3 Dagmar von Lisingen e Idaleto Aued ja eram estagıaı ıos quando Jane e eu chegamos Os bolsıstas de inıciaçao cientıfica da graduação em Ciências Socıaıs tambem particıpavam dos seminarios 